begrepsdefinisjoner, et avsnitt om generell undersøkelsessystematikk, deretter en grundigere gjennomgang av undersøkelsen av de ulike abdominalorganene.

Mer avanserte modaliteter, inkludert motilitetsundersøkelser, kontrastundersøkelser og endoskopisk ultralyd, er også med, men uten å få mer plass enn det fortjener $i$ en utgivelse for denne målgruppen.

Som forfatterne selv skriver er Innføring $i$ abdominal ultralyd egnet for både nybegynnere og dem som har noe mer erfaring med ultralydundersøkelser av abdomen. I tillegg egner den seg altså som stimulerende appetittvekker for dem som har ment at ultralyd er viktigere enn den plassen det har fått $\mathrm{i}$ egen praksis. Det finnes en rekke mer omfattende lærebøker for dem som vil videre, men denne vil trolig få flere til å komme i gang.

Det er lite å utsette på denne utgivelsen. Den fortjener tilsvarende vid utbredelse i Norge, som et glimrende supplement til de øvrige utdanningstilbudene som etter hvert finnes innen gastrointestinal ultralyd.

\section{Lars Aabakken}

Medisinsk avdeling

Oslo universitetssykehus, Rikshospitalet

\section{Et viktig budskap}

Broeng S, red

Fokus på relationer

Psykiatri i praksis. 239 s, ill. København:

Hans Reitzels Forlag, 2009. Pris DKK 298 ISBN 978-87-412-5215-5

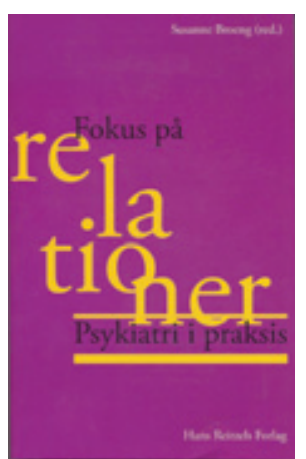

Ifølge redaktøren henvender man seg til «studerende og fagfolk inden for det sociale, psykologiske, sundhedsfaglige og pædagogiske område, det vil sige alle de forskjellige fagpersoner, der i deres arbeijdsliv møder patienter og pårørende og skal bidrage til at skabe udviklende processer for personer, der har fået diagnosticeret en sindslidelse». Vi får en innføring i betydningen av mellommenneskelige relasjoner i psykiatrisk behandling. I åtte kapitler beskrives historikk, teorigrunnlag og praksis på relativt bred front.

Fokus på relationer bør ønskes velkommen av flere grunner. For det første har vi innen psykiatrien vært vitne til en nesten eksplosiv økning i biologisk kunnskap. For det annet har økte krav om rask og effektiv «leveranse av helsetjenester» ført til vektlegging av raske prosesser og riktige håndgrep. Begge disse kan lett føre til at relasjo- nelle faktorer overses. Behandling står i fare for å bli en teknisk prosedyre hvor møtet mellom mennesker får lite rom. Her dokumenteres det på en etter min mening overbevisende måte hvor viktig det er å ta vare på mellommenneskelige relasjoner. Jeg tror at alle som arbeider i psykiatriske institusjoner vil ha utbytte av å lese dette, spesielt de mer praktisk rettede kapitlene.

Kapitlene om historikk og teori er mer ujevne. Den svakeste delen er etter min mening den som omhandler institusjonspsykiatriens historie. Den er mangelfullt beskrevet. Det er selvsagt en vanskelig avveining hvor mye man kan ta med $i$ en innføringsbok. Men hvis det skulle tas med et avsnitt om historien, burde man i hvert fall ha gitt plass til en omtale av det terapeutiske samfunn.

Et viktig spørsmål til slutt: Det er litt uklart hvordan denne utgivelsen er tenkt brukt. Den inneholder en del øvelser i form av rollespill og refleksjoner over eget liv. Disse øvelsene kan helt sikkert være meget verdifulle, men vil etter min oppfatning forutsette en kyndig ledelse. I boken sies det imidlertid ikke noe om det. Det burde ha vært noen råd om nødvendige rammebetingelser.

\section{Svein Friis}

Psykiatrisk divisjon

Oslo universitetssykehus, Ullevål

\section{Multidisiplinært om ungdom og seksualitet}

Magnusson C, Häggström-Nordin E, red. Ungdomar, sexualitet och relationer

376 s, ill, tab. Lund: Studentlitteratur, 2009. Pris SEK 373

ISBN 978-91-44-04934-2

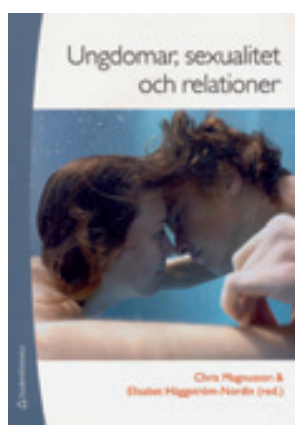

Utgiverne henvender seg til universitets- og høyskolestudenter samt faggrupper innen helsevesenet, skole og ellers i samfunnet. De ønsker at boken skal være anvendbar både i utdanning, innen sexologi og i praksis som grunnlag

for det forebyggende arbeidet. Den fremstår som en godt dokumentert lærebok der forfatternes intensjon er å gi et helhetsperspektiv på ungdom og seksualitet.

Det starter med presentasjon av de 16 forfatterne, representanter for myndighetene, virksomheter og forskning innen ulike disipliner, noe som til sammen gir et helhetsperspektiv på emnet. Tanken er at sek- sualitet ikke skal studeres som et isolert fenomen, men ses i større sammenheng. Hovedvekten ligger på det folkehelsevitenskapelige, det samfunnsvitenskapelige/ sosiologiske samt det psykologiske perspektivet. Innholdet strekker seg fra presentasjon av relevant forskning til at ungdommene selv får komme til orde i form av utdrag av en rekke samtaler og intervjuer fra ungdomshelsestasjoner og videregående skole.

Forfatterne redegjør for ulike aspekter av ungdommens seksuelle utvikling og atferd samt konstruksjon av kjønn og seksualitet, seksualitetens rolle $\mathrm{i}$ tenårene, reproduktiv helse og risikoatferd.

Kjønnsperspektivet kommer klart frem ved at gutter og jenter er omtalt $i$ egne kapitler. Særlig positivt er det at også spesielle grupper - de som er annerledes, med funksjonshemninger, har innvandrerbakgrunn - er viet egne kapitler der spesielle aspekter og behov kommer godt frem. De ulike innfallsvinklene gir et bredt og nyansert bilde av ungdom og seksualitet. Både positive og negative tendenser blir diskutert, og det vurderes også fremtidsvisjoner innen feltet. Til sammen gir dette en plattform som kan legges til grunn for planleggingen av forebyggende arbeid.

Språket er svensk, noe som kan være en utfordring å lese, særlig de kapitlene som er mest teoretiske og dermed mest preget av fagspråk. Hvert kapittel avsluttes med en lang og solid referanseliste, likevel blir teksten i flere av kapitlene forstyrret av et utall tekstlige referansehenvisninger i parentes. Med hell kunne henvisningene heller vært nummerert i forhold til referanselistene.

Det er kun noen få illustrasjoner og tabeller, det kunne gjerne vært flere. Gode illustrasjoner og bilder kan fremheve innholden i teksten og myke opp inntrykket. Ungdomar, sexualitet och relationer er i paperback, og trykkeprosess og innbinding har foregått på en miljøvennlig måte.

Som lærebok er dette en interessant utgivelse. Den er grundig og allsidig, ikke minst inneholder den mange nyttige referanser. Når den i tillegg omtaler seksualitet innen grupper i samfunnet det finnes lite annen litteratur om, bør den også kunne benyttes i praksisfeltet. Imidlertid må man være klar over at mye av stoffet beskriver svenske forhold, og at man ikke på alle områder kan trekke direkte paralleller til norske.

\section{Siv Gamnes}

Sex og samfunn

Senter for ung seksualitet

Oslo 